\title{
AQUARIA KEPT MARINE FISH SPECIES POSSIBLY RELEASED IN THE MEDITERRANE- AN SEA: FIRST CONFIRMATION OF INTENTIONAL RELEASE IN THE WILD
}

\author{
Argyro ZENETOS ${ }^{1 *}$, Georgos APOSTOLOPOULOS ${ }^{2}$, and Fabio CROCETTA ${ }^{1}$ \\ ${ }^{1}$ Institute of Marine Biological Resources and Inland Waters, Hellenic Centre for Marine Research, Anavissos, Greece \\ ${ }^{2}$ Kallidromiou 41, Athens, GR-10681, Greece
}

Zenetos A., Apostolopoulos G., Crocetta F. 2016. Aquaria kept marine fish species possibly released in the Mediterranean Sea: First confirmation of intentional release in the wild. Acta Ichthyol. Piscat. 46 (3): $255-262$.

\begin{abstract}
This work reviews the introduced marine fish species in the Mediterranean Sea, whose mechanism of introduction is potentially linked to aquarium trade. The list includes 19 species, all listed in FishBase as commercially exploited species in the aquarium trade. Whilst transport-stowaway (shipping) may be considered as a potential pathway for almost all of them, 7 of these also live in the Red Sea, and therefore could have entered unintentionally via the Suez Canal. We also here report the first Mediterranean sighting of the emperor red snapper, Lutjanus sebae (Cuvier, 1816), on the basis of one specimen sampled in Saronikos Gulf. A research carried out by one of the authors led us to trace its entire life in Greece, from the presence in a local pet store to its intentional release in nature and subsequent collection.
\end{abstract}

Keywords: marine aquarium hobbyist, alien fish, Lutjanus sebae, Greece

The aquarium trade is responsible for transportation of thousands of species around the world. With the recent fashion of keeping salt-water aquaria, some of the ornamental species may be intentionally released into marine waters, where they potentially survive and become Aquatic Nuisance Species (ANS) (Krishnakumar et al. 2009, MacedaVeiga et al. 2013). Indeed, the aquarium trade has recently been recognized as the fourth significant pathway for the introduction of fishes, invertebrates, and plants in European seas after shipping, corridors, and aquaculture (Katsanevakis et al. 2013a, Essl et al. 2015). Yet, the threat posed to coastal ecosystems by the aquarium trade as a mechanism of species transfer remains largely unquantified, mostly due to absence of concrete evidence (Weigle et al. 2005).

According to Liveaquaria**, one of the biggest websites dealing with aquarium trade, approximately 415 marine fishes are traded for salt-water aquaria worldwide. In the Mediterranean Sea, by 2012, some 18 species, including 13 tropical fishes, were assumed to be introduced by aquarium trade release in nature (Zenetos et al. 2012). According to new data on these species and records of additional taxa from the Mediterranean Sea, the number has increased in the last years. We hereby review and update the fish species suspected as introduced in the Mediterranean via aquarium trade by 2016 , and document the first Mediterranean occurrence of the emperor red snapper, Lutjanus sebae (Cuvier, 1816).
The review of fish taxa possibly introduced in the Mediterranean by aquarium trade (release in nature) is based on the Mediterranean HCMR/EEA (Hellenic Centre for Marine Research/European Environment Agency) alien species database, archived in EASIN (European Alien Species Information Network) (Katsanevakis et al. 2013b, 2015). FishBase (Froese and Pauly 2016), as well as other websites, were screened for marine aquarium species. Among those encountered by us, Liveaquaria was the one with most species listed, including the majority of species already reported by other websites of minor importance. The updated list of possible aquarium releases in the Mediterranean Sea by July 2016 is provided in Table 1 . Among the species listed in Table 1, some records are based on photographs, which makes them less reliable than records based on examined specimen(s). It should be noted that conservative ichthyologists do not consider photographic evidence as a substantiated record of a species. Phylogenetic listing follows Betancur-R et al. (2013) and Santini et al. (2013). Lower-level taxonomy and nomenclature follows the World Register of Marine Species (WoRMS Editorial Board 2016). Species list was also enriched by information on main native range (amended from FishBase), possible pathway/s and pathway certainty. Possible pathways were both taken from original publications and re-assessed by the authors after researches (see above) on which taxa are commercially exploited in private/public aquaria.

\footnotetext{
* Correspondence: Dr. Argyro Zenetos, Institute of Marine Biological Resources and Inland Waters, Hellenic Centre for Marine Research, Anavissos, GR-19013, Greece, phone: +30 210 9856701, fax: +302109811713, e-mail: (AZ) zenetos@hcmr.gr, (GA) apogeorge1@hotmail.com, (FC)fabiocrocetta@hcmr.gr

** http://www.liveaquaria.com
} 


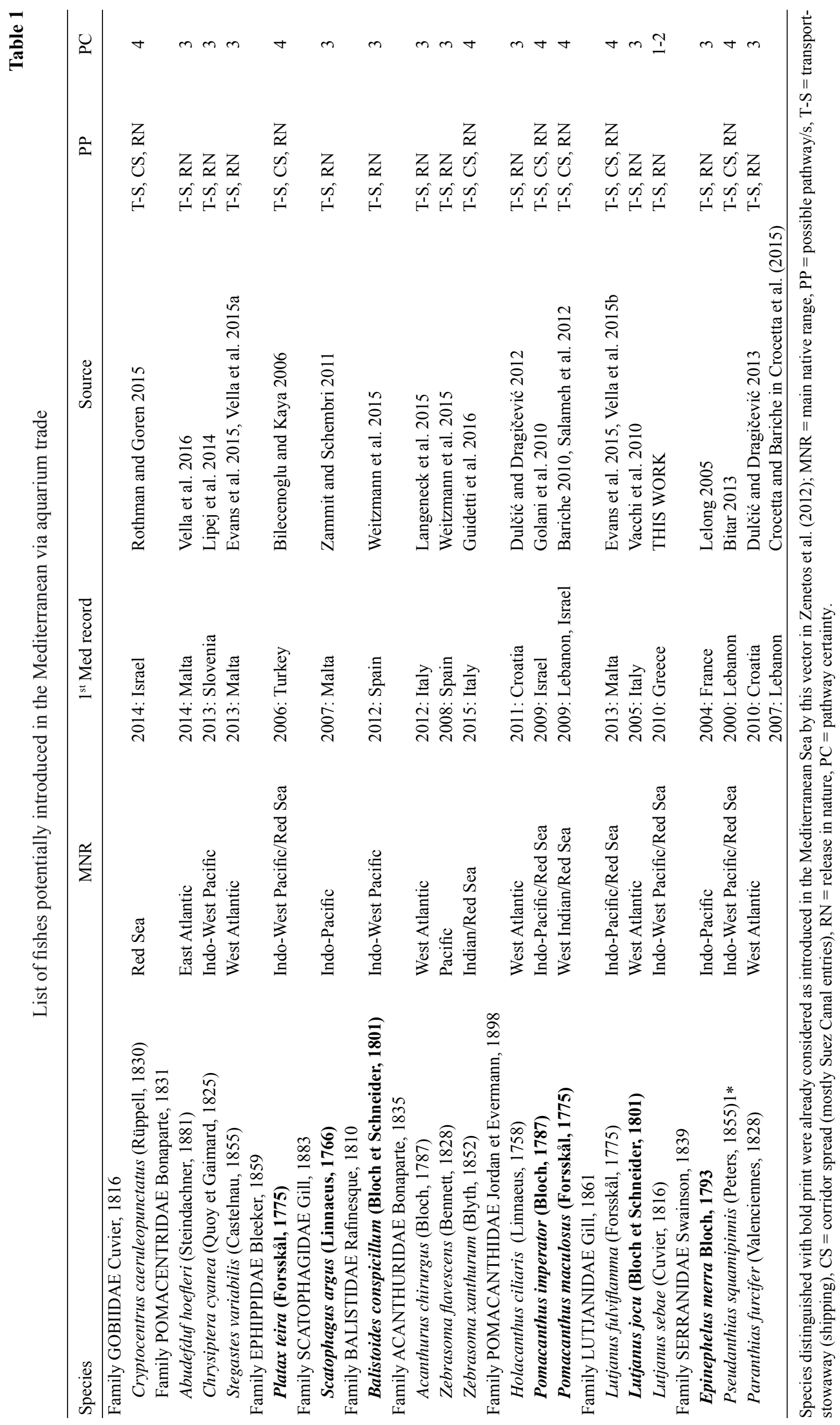


Pathway nomenclature follows the Convention on Biological Diversity (Anonymous 2014). The certainty in assigning a pathway follows that described in Katsanevakis et al. (2013a) and is again more briefly reported here:

- There is direct evidence of a pathway/vector;

- A most likely pathway/vector can be inferred;

- One or more possible pathways/vectors can be inferred;

- Unknown: where there is doubt as to any specific pathway explaining an arrival.

In December 2010, a Greek fisherman (Plato Sarantidis) caught a strange colourful fish in Lagonissi (Saronikos Gulf), during a commercial fishing trawl at a depth of $\sim 20 \mathrm{~m}$ near a Posidonia oceanica meadow. The fish, which was transferred to the aquarium of one of the authors (GA), did not survive long, as it was injured. The possible presence of this species in the aquarium trade shops of the wider Athens area was investigated.

The number of potential aquarium trade transported fish species in the Mediterranean has increased drastically since the latest review Zenetos et al. (2012). In most cases aquarium trade appears to be the responsible mechanism for the transport of these species. This is due to sporadic findings of peculiar and colourful fish taxa, far away from their native range and from introduction corridors (Gibraltar Strait for the tropical Atlantic species and the Suez Canal area for Indo-Pacific ones). The degree, however, of certainty/uncertainty remains high for all of them due to lack of concrete evidence, and therefore even other pathways may be also responsible for their transportation in the Mediterranean. This can be moreover argued for both tropical species occurring in the Red Sea such as Pomacanthus maculosus (Forsskål, 1775), or even for Atlantic species, such as Paranthias furcifer (Valenciennes, 1828) and Holacanthus ciliaris (Linnaeus, 1758) (see Table 1). Some ichthyologists have other hypotheses as to their route of invasion. Yet, out of the 13 fish species previously assigned to this pathway (Zenetos et al. 2012), six species namely: Heniochus intermedius Steindachner, 1893, Ostracion cubicus Linnaeus, 1758, Pterois miles (Bennett, 1828), Lutjanus argentimaculatus (Forsskål, 1775), Iniistius pavo (Valenciennes, 1840), and Selene dorsalis (Gill, 1863) have been subsequently excluded. This is either because of subsequent records in the Levantine that provided additional evidences through a Lessepsian migration (such is the case for: $H$. intermedius, $O$. cubicus, $P$. miles, and $L$. argentimaculatus: see Tsadok et al. 2015, Erguden et al. 2016, Crocetta and Bariche in Dailianis et al. 2016, Kletou et al. 2016), or reassignment as range expanders ( $S$. dorsalis) or exclusion as misidentification (Iniistius pavo being a juvenile of the native Xyrichtys novacula (Linnaeus, 1758): see questionable status in Corsini et al. 2015). However, 7 species of the original bulk are still listed as such, and these are distinguished in bold print in Table 1. We also highlight here that for several taxa of the original bulk, as well as for some new entries, aquarium trade has not been previously reported as the potential mode of their introduction. This may have happened due to lack of appropriate researches on this possibility.
In addition, two further species, Plectorhinchus gaterinus (Forsskål, 1775) and Pomacanthus asfur (Forsskål, 1775), were recently recorded from the Mediterranean Sea as potential aquarium releases. The former was recorded from Greece with reservations, as based on a single specimen found while emptying and cleaning the stomach of a specimen of an European squid, Loligo vulgaris (see Corsini-Foka and Sarlis 2016). Pending uncertainties regarding the finding, we have excluded it from our list. On the contrary, the record of Pomacanthus asfur (see Deidun and Bonnici in Karachle et al. 2016) was evidently based on a misidentification for P. maculosus, which in turn was already recorded from Lebanon and Israel (Bariche 2010, Salameh et al. 2012) and was suspected of being an aquarium release.

Among fishes potentially introduced in the Mediterranean as aquarium releases, species belonging to Acanthuridae Bonaparte, 1835 and Lutjanidae Gill, 1861 need a mention. Five acanthurids have been reported from the Mediterranean to date. The Atlantic originatedAcanthurus monroviae Steindachner, 1876-which has been reported in the Mediterranean since 1983 (Crespo et al. 1987: Spain), has presumably entered the Mediterranean Sea unintentionally via Gibraltar. Of the remaining four, Acanthurus coeruleus Bloch et Schneider, 1801 was initially suspected to be aquarium trade release (Langeneck et al. 2012), an assumption later rejected in the light of new evidence (Golani et al. 2015). However, the presence of sporadic records of the other three species (see Table 1) is likely to be related to accidental releases from tropical aquaria, including the aquaria possibly set up on megayachts, which are very common in summer in touristic areas, like NE Sardinia (Langeneck et al. 2015, Weitzmann et al. 2015, Guidetti et al. 2016). Although their quite large adult size and their particular feeding habits make the rearing in captivity of most Acanthuridae difficult, these fish are fairly common in the aquarium trade, and a diversity of species can be found in aquarium shops (Papavlasopoulou et al. 2014). With regards to Lutjanidae, three species have been reported among aliens in Mediterranean so far, and a further taxon is first recorded in this work. With the sole exception of Lutjanus argentimaculatus (Forsskål, 1775), an Indo-Pacific species whose most possible way of transfer in the Mediterranean is now here assumed to be the Suez Canal in the light of old and recent records from Lebanon (Mouneimné 1979, Crocetta and Bariche in Dailianis et al. 2016), all the other species may have been easily introduced in the Mediterranean via aquarium release. It is the case of the west Atlantic taxon Lutjanus jocu (Bloch et Schneider, 1801), only recorded in Mediterranean from the Ligurian Sea (Vacchi et al. 2010). If not an aquarium introduced species, it may have been a migrant from Gibraltar or more likely a species introduced by ships (Vacchi et al. 2010). The third species, Lutjanus fulviflamma (Forsskål, 1775) might also have been introduced via shipping as this specimen was collected from a harbour which is regularly visited by large commercial ships, or is an aquarium release from marine vessels visiting the Grand Harbour (Vella et al. 2015b). 
Other suspects, whose introduction in the Mediterranean Sea could be linked to the aquarium trade (Table 1) include the queen angelfish, Holacanthus ciliaris (Linnaeus, 1758), and the Atlantic creolefish, Paranthias furcifer (Valenciennes, 1828), in Croatia (Dulčić and Dragičević 2012, 2013). These are both aquarium commercial species and, although the authors declared that according to information obtained from the State Institute for Nature Protection there were no requests for these species from major importers of aquarium fishes in Croatia, this does not imply that they were not imported in Croatia. It is worth mentioning that, however, a further Mediterranean record of $P$. furcifer comes from Lebanon (Crocetta and Bariche in Crocetta et al. 2015), but no follow up exists from any of the Mediterranean countries between the two abovementioned. Therefore, or the species may have entered naturally in the Mediterranean Sea, or we may be dealing with two different introduction events.

The emperor red snapper, Lutjanus sebae belongs to Lutjanidae Gill, 1861 and usually occurs on coral reefs and rubble seabeds down to the depth of $100 \mathrm{~m}$, although juveniles and young adults occur in shallow inshore reefs, whilst adults live deeper. It is a large species (up to $120 \mathrm{~cm}$ total length) with dorsal profile of head steeply sloped, body elongate oval and moderately compressed, and single dorsal fin neatly divided into two parts with 11 spines plus $15-16$ soft rays. Anal fin heavily thorny in the fore part and composed of three spines plus 10-11 rays, pectoral fins with 17 rays, reaching soft anal fin. Caudal fin moderately forked. Adults colour pattern pink or red. Younger fishes marked with three distinct and verticaloblique darker bands: the first extends from front of dorsal fin through eye and tip of snout, the second crosses mid-body region, from mid-dorsal fin to anal fin passing just behind the pectoral fin, the third originating at the rear of dorsal fin and extending up to the lower corner of the caudal fin. Lutjanus sebae is considered native to the Indo-West Pacific (southern
Red Sea and East Africa to New Caledonia, north to southern Japan, south to Australia) (Froese and Pauly 2016) and has never been recorded from the Mediterranean Sea. One single specimen of $\sim 12 \mathrm{~cm}$ in total length, identified as such following Allen (1985), was captured in an area of Saronikos Gulf near Athens and the port of Piraeus in December 2010. Despite the importance of such a finding, the specimen has not been preserved, although a photo of the sample was taken by one of the authors (GA) (Fig. 1). Considering that the Saronikos Gulf is very far from the Suez Canal entrance in Port-Said (Egypt), and that the species is not known from further Mediterranean areas, two possible pathways were potentially assumed for this finding:

- It might have been transferred via shipping (in ships' sea-chests) from the numerous ships that visit the port of Piraeus;

- It might have been introduced as an aquarium release.

Within recent years, salt-water aquaria with tropical marine species have become a common hobby in Greece. After some investigations in several aquarium shops, Mr Apostolis Ladopoulos (owner of a shop and very well informed on tropical fish species) helped us solving the matter. He reported us that an aquarium hobbyist bought a Lutjanus sebae, which was seemed to be "rapidly" growing in his aquarium. As it was also a big predator feeding on the other species living in his aquarium, the hobbyist decided to release it in Lagonissi (Saronikos Gulf). Although he was not sure about the month, it was possibly October 2009. The hobbyist used to visit by snorkelling the place where the $L$. sebae had been released, and he always found the fish near a small cave. However, he finally lost sight of it after some weeks.

Although, we had no $100 \%$ scientific proof, that we were dealing with the same specimen, the release in nature surely happened. However, being our specimen found more or less in the same area where it was originally

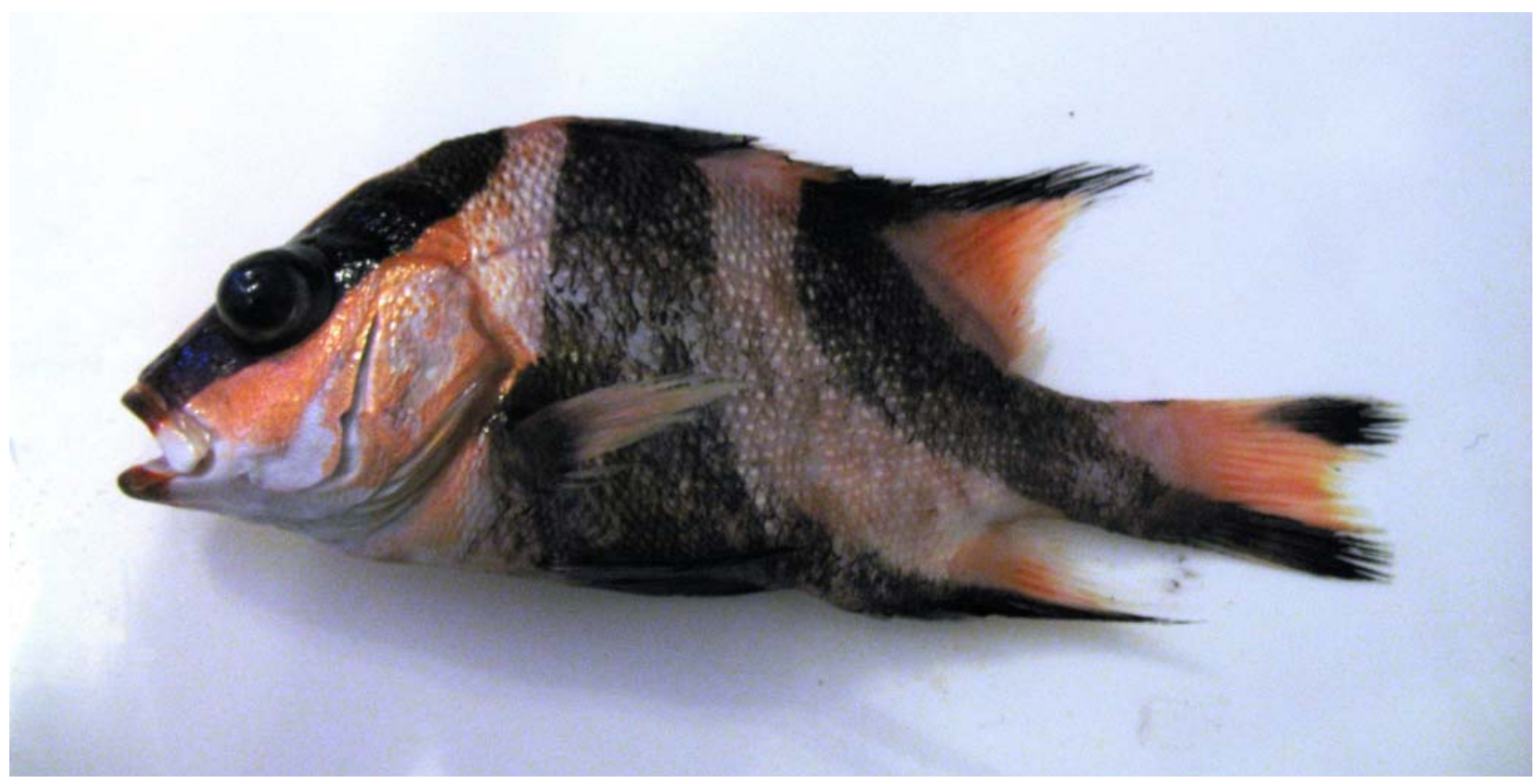

Fig. 1. Emperor red snapper, Lutjanus sebae, from Saronikos Gulf ( $\sim 12 \mathrm{~cm}$ total length) 
released, and since we are dealing with the same taxon, we are quite confident in speculating that the specimen fished by Mr Plato Sarantidis is the same one that was released in the field some time earlier by the hobbyist. Indeed the depth at which the fish was found is different with respect to the one where it was usually observed by the hobbyist. As an explanation, it is possible that Lutjanus sebae migrated in a deeper place as soon as the winter 20092010 began and the water got colder. As mentioned above, the fish did not survive long in the captivity of the author's (GA) aquarium, as it was injured. Effects of release method on survival in the red emperor have been tested experimentally. The results demonstrated the superiority of vertical enclosures over small cages for testing shortterm survival (Brown et al. 2010). The interesting fact is that the fish survived some winter months in Saronikos Gulf. From in situ measurements in the area, the mean water column temperature during the winter of 20092010 ranged between 15 and $16^{\circ} \mathrm{C}$ with a mean winter temperature of $15.25^{\circ} \mathrm{C}$ (Anonymous, unpublished ${ }^{*}$ ).

General remarks. A third of the world's worst aquatic invasive species are aquarium or ornamental species (Padilla and Williams 2004). According to Papavlasopoulou et al. (2014), based on store labels, Lutjanus sebae is not listed among the ornamental marine fish in pet stores in Greece. Yet, an intensive investigation has revealed that it is available in retail pet shops. Mislabelling could be a possible explanation for it. In the USA, mislabelling has been documented in $27 \%$ of cases in marketed aquaria products (shipments were often mislabelled to contain marine fish when they in fact harboured only freshwater fish, corals, and/or other wildlife products) (Rhyne et al. 2012). Members of the genus Lutjanus are exported as ornamental fish both in the Indo-Pacific (Jayalal and Ramachandran 2012) and the Atlantic Ocean (MonteiroNeto et al. 2003). Since snappers are opportunistic feeders and have an aggressive feeding behaviour (Grandcourt et al. 2008), they may be a threat to native populations of fish, up to the point of their total displacement (Friedlander et al. 2002).

In Australia, a country with relatively stringent import controls, many of the more than 200 species imported have the potential to become invasive. Regulatory measures include the use of lists of permitted species, a case-by-case risk assessment process for species not on these lists, and requirements for health certification and quarantining of imported stock (Morrisey et al. 2011). In the Mediterranean Sea, with its variety of environments, and the exponentially increasing number of potential aquarium releases as inferred from the literature, the need to quantify the exact number of species belonging to all phyla potentially introduced in the field as aquarium introduced species, as well as their impact, is imperative.

\section{ACKNOWLEDGMENTS}

We wish to thank the professional fisherman Mr Plato Sarantidis, who captured the specimen, and Mr Apostolis Ladopoulos, the owner of an aquarium shop in Athens, who provided the information about the fish release in Saronikos Gulf. The study of the alien species from Greece was partially funded by the East and South European Network for Invasive Alien Species - a tool to support the management of alien species in Bulgaria (ESENIAS-TOOLS) (EEA funded-Contract No. D-3351/30.06.2015) (FC and AZ) and the COST (European Cooperation in Science and Technology) Action TD1209 Alien Challenge (FC) projects.

\section{REFERENCES}

Allen G.R. 1985. FAO species catalogue. Vol. 6. Snappers of the world. An annotated and illustrated catalogue of lutjanid species known to date. FAO Fisheries Synopsis No. 125: 1-208.

Anonymous 2014. Pathways of introduction of invasive species, their prioritization and management. Convention on Biological Diversity: UNEP/CBD/SBSTTA/18/9/ Add.1. https://www.cbd.int/doc/meetings/sbstta/sbstta-18/ official/sbstta-18-09-add1-en.pdf

Bariche M. 2010. First record of the angelfish Pomacanthus maculosus (Teleostei: Pomacanthidae) in the Mediterranean. Aqua 16 (1): 31-33.

Betancur-R. R., Broughton R.E., Wiley E.O., Carpenter K., López J.A., Li C., Holcroft N.I., Arcila D., Sanciangco M., Cureton II J.C., Zhang F., Buser T., Campbell M.A., Ballesteros J.A., Roa-Varon A., Willis S., Borden W.C., Rowley T., Reneau P.C., Hough D.J., Lu G., Grande T., Arratia G., Ortí G. 2013. The tree of life and a new classification of bony fishes. PLOS Currents Tree of Life 2013 Apr 18. Edition 1.

DOI: 10.1371/currents.tol.53ba26640df0ccaee75bb165c8c26288

Bilecenoglu M., Kaya M. 2006. A new alien fish in the Mediterranean Sea-Platax teira (Forsskål, 1775) (Osteichthyes: Ephippidae). Aquatic Invasions 1 (2): 80-83.

DOI 10.3391/ai.2006.1.2.5

Bitar G. 2013. Sur la présence des poissons exotiques nouveaux de la côte libanaise (Méditerranée orientale). Rapport Commission international Mer Méditerranée 40: 592.

Brown I., Sumpton W., McLennan M., Mayer D., Campbell M., Kirkwood J., Butcher A., Halliday I., Mapleston A., Welch D., Begg G.A., Sawynok B. 2010. An improved technique for estimating short-term survival of released line-caught fish, and an application comparing barotrauma-relief methods in red emperor (Lutjanus sebae Cuvier 1816). Journal of Experimental Marine Biology and Ecology 385 (1-2): 1-7.

DOI: $10.1016 /$ j.jembe.2010.01.007

Corsini-Foka M., Sarlis N. 2016. A strange occurrence of Plectorhinchus gaterinus (Actinopterygii: Perciformes: Haemulidae) in the Thracian Sea (eastern Mediterranean). Acta Ichthyologica et Piscatoria 46 (1): $37-41$.

DOI: $10.3750 / A I P 2016.46 .1 .05$

* Anonymous 2012. Monitoring of the Saronikos Gulf affected by the Psittalia Sewage Treatment Plant outfall. (EYDAP) Special Service Public Works for the greater Athens Area sewerage and sewage treatment. HCMR technical report. [In Greek.] 
Corsini-Foka M., Zenetos A., Crocetta F., Çinar M.E., Koçak F., Golani D., Katsanevakis S., Tsiamis K., Cook E., Froglia C., Triandaphyllou M., Lakkis S., Kondylatos G., Tricarico E., Zuljevic A., Almeida M., Cardigos F., Çağlar S., Durucan F., Fernandes A.M.D., Ferrario J., Haberle I., Louizidou P., Makris J., Marić M., Micu D., Mifsud C., Nall C., Kytinou E., Poursanidis D., Spigoli D., Stasolla G., Yapici S., Roy H.E. 2015. Inventory of alien and cryptogenic species of the Dodecanese (Aegean Sea, Greece): Collaboration through COST Action training school. Management of Biological Invasions 6 (4): 351-366.

DOI: $10.3391 / \mathrm{mbi} .2015 .6 .4 .04$

Crespo J., Rey J.C., García A. 1987. Primera cita de Acanthurus monrovae Steindachner, 1876 y de Diodon eydouxii Brissout de Barneville, 1846, para la ictiofauna europea. Miscel-lània Zoològica 11: 271-275.

Crocetta F., Agius D., Balistreri P., Bariche M., Bayhan Y.K., Çakir M., Ciriaco S., CorsiniFoka M., Deduin A., El Zrelli R., Ergüden D., Evans J., Ghelia M., Giavasi M., Kleitou P., Kondylatos G., Lipej L., Mifsud C., Özvarol Y., Pagano A., Portelli P., Poursanidis D., Rabaoui L., Schembri P.J., Taşkin E., Tiralongo F., Zenetos A. 2015. New Mediterranean biodiversity records (October 2015). Mediterranean Marine Science 16 (3): 682-702. DOI: $10.12681 / \mathrm{mms} .1477$

Dailianis T., Akyol O., Babali N., Bariche M., Crocetta F., Gerovasileiou V., Ghanem R., Gökoğlu M., Hasiotis T., Izquierdo-Muñoz A., Julian D., Katsanevakis S., Lipej L., Mancini E., Mytilineou C., Ounifi Ben Amor K., Özgül A., Ragkousis M., Rubio-Portillo E., Servello G., Sini M., Stamouli C., Sterioti A., Teker S., Tiralongo F., Trkov D. 2016. New Mediterranean biodiversity records (July 2016). Mediterranean Marine Science 17 (2): 608-626.

DOI: $10.12681 / \mathrm{mms} .1734$

Dulčić J., Dragičević B. 2012. Holacanthus ciliaris (Linnaeus, 1758) (Teleostei: Pomacanthidae), first record from the Mediterranean Sea. Journal of Applied Ichthyology 29 (2): 465-467.

DOI: $10.1111 /$ jai.12096

Dulčić J., Dragičević B. 2013. Paranthias furcifer (Perciformes: Serranidae), a new alien fish in the Mediterranean Sea. Journal of Fish Biology 82 (1): 332-337. DOI: 10.1111/j.1095-8649.2012.03462.x

Erguden D., Çekiç M., Erguden S.A., Turan C. 2016. Occurrence of Heniochus intermedius Steindachner, 1893 in Iskenderun Bay, Turkey. Journal of Applied Ichthyology 32 (2): 375-376. DOI: $10.1111 /$ jai.13013

Essl F., Bacher S., Blackburn T., Booy O., Brundu G., Brunel S., Cardoso A.C., Eschen R., Gallardo B., Galil B., Garcia-Berthou E., Genovesi P., Groom
Q., Harrower C., Hulme P.E., Katsanevakis S., Kenis M., Kühn I., Kumschick S., Martinou A.F., Nentwig W., O'Flynn C., Pagad S., Jan Pergl J., Pyšek P., Rabitsch W., Richardson D.M., Roques A., Roy H.E., Scalera R., Schindler S., Seebens H., Vanderhoeven S., Vila M., Wilson J.R.U., Zenetos A., Jeschke J.M. 2015. Crossing frontiers in tackling pathways of biological invasions. BioScience 65 (8): 769-782.

DOI: $10.1093 /$ biosci/biv082

Evans J., Barbara J., Schembri P.J. 2015. Updated review of marine alien species and other 'newcomers' recorded from the Maltese Islands (central Mediterranean). Mediterranean Marine Science 16 (1): 225-244.

DOI: $10.12681 / \mathrm{mms} .1064$

Friedlander M., Parrish J.D., DeFelice R.C. 2002. Ecology of the introduced snapper Lutjanus kasmiva (Forsskal) in the reef fish assemblage of a Hawaiian bay. Journal of Fish Biology 60 (1): $28-48$.

DOI: 10.1111/j.1095-8649.2002.tb02386.x

Froese R., Pauly D. (eds.) 2016. FishBase. [Version 01/2016] www.fishbase.org

Golani D., Askarov G., Appelbaum-Golani B. 2015. First confirmed record of the blue tang, Acanthurus coeruleus (Actinopterygii: Perciformes: Acanthuridae) in the Mediterranean. Acta Ichthyologica et Piscatoria 45 (3): 311-313. DOI: 10.3750/AIP2015.45.3.10

Golani D., Salameh P., Sonin O. 2010. First record of the emperor angelfish, Pomacanthus imperator (Teleostei: Pomacanthidae) and the second record of the spotbase burrfish Cyclichthys spilostylus (Teleostei: Diodontidae) in the Mediterranean. Aquatic Invasions 5 (Suppl. 1): S41-S43.

DOI: 10.3391/ai.2010.5.S1.010

Grandcourt E.M., Hecht T., Booth A.J., Robinson J. 2008. Retrospective stock assessment of the emperor red snapper (Lutjanus sebae) on the Seychelles Bank between 1977 and 2006. ICES Journal of Marine Science 65 (6): 889-898. DOI: 10.1093 /icesjms/fsn064

Guidetti P., Magnani L., Navone A. 2016. First record of the acanthurid fish Zebrasoma xanthurum (Blyth, 1852) in the Mediterranean Sea, with some considerations on the risk associated with aquarium trade. Mediterranean Marine Science 17 (1): $147-151$.

DOI: $10.12681 / \mathrm{mms} .1470$

Jayalal L., Ramachandran A. 2012. Export trend of Indian ornamental fish industry. Agriculture and Biology Journal of North America 3 (11): 439-451. DOI: 10.5251/abjna.2012.3.11.439.451

Karachle P.K., Angelidis A., Apostolopoulos G., Ayas D., Ballesteros M., Bonnici C., Brodersen M.M., Castriota L., Chalari N., Cottalorda J.M., Crocetta F., Deidun A., Đođo Ž., Dogrammatzi A., Dulčić J., Fiorentino F., Gönülal O., Harmelin 
J.G., Insacco G., Izquierdo-Gómez D., IzquierdoMünoz A., Joksimović A., Kavadas S., Malaquias M.A.E., Madrenas E., Massi D., Micarelli P., Minchin D., Önal U., Ovalis P., Poursanidis D., Siapatis A., Sperone E., Spinelli A., Stamouli C., Tiralongo F., Tunçer S., Yaglioglu D., Zava B., Zenetos A. 2016. New Mediterranean biodiversity records (March 2016). Mediterranean Marine Science 17 (1): 230-252.

DOI: $10.12681 / \mathrm{mms} .1684$

Katsanevakis S., Deriu I., D'Amico F., Nunes A.L., Pelaez Sanchez S., Crocetta F., Arianoutsou M., Bazos I., Christopoulou A., Curto G., Delipetrou P., Kokkoris Y., Panov V., Rabitsch W., Roques A., Scalera R., Shirley S.M., Tricarico E., Vannini A., Zenetos A., Zervou S., Zikos A., Cardoso A.C. 2015. European Alien Species Information Network (EASIN): Supporting European policies and scientific research. Management of Biological Invasions 6 (2): 147-157. DOI: $10.3391 / \mathrm{mbi} .2015 .6 .2 .05$

Katsanevakis S., Zenetos A., Belchior C., Cardoso A.C. 2013a. Invading European seas: Assessing pathways of introduction of marine aliens. Ocean and Coastal Management 76: 64-74. DOI: 10.1016/j. ocecoaman.2013.02.024

Katsanevakis S., Zenetos A., Poursanidis D., Nunes A.L., Deriu I., Bogucarskis K., Cardoso A.C. 2013b. ELNAIS meets EASIN: Distribution of marine alien species in Greece using EASIN mapping services and ELNAIS spatial data. Mediterranean Marine Science 14 (1): 95-98. DOI: $10.12681 / \mathrm{mms} .329$

Kletou D., Hall-Spencer J.M., Kleitou P. 2016. A lionfish (Pterois miles) invasion has begun in the Mediterranean Sea. Marine Biodiversity Records 9: 46.

DOI: $10.1186 / \mathrm{s} 41200-016-0065-\mathrm{y}$

Krishnakumar K., Raghavan R., Prasad G., Bijukumar A., Sekharan M., Pereira B., Ali A. 2009. When pets become pests - exotic aquarium fishes and biological invasions in Kerala, India. Current Science 97 (4): 474-476.

Langeneck J., Boyer M., De Cecco P.G., Luciani C., Marcelli M., Vacchi M. 2015. First record of Acanthurus chirurgus (Perciformes: Acanthuridae) in the Mediterranean Sea, with some distributional notes on Mediterranean Acanthuridae. Mediterranean Marine Science 16 (2): 427-431.

DOI: $10.12681 / \mathrm{mms} .1239$

Langeneck J., Marcelli M., Simak H.C. 2012. Unexpected alien species in Cyprus waters: Acanthurus coeruleus (Actinopterygii: Acanthuridae). Marine Biodiversity Records 5: e116. DOI: $10.1017 / \mathrm{S} 1755267212001042$

Lelong P. 2005. Capture d'un macabit, Epinephelus merra Bloch, 1793 (Poisson, Serranidae), en Méditerranée nord-occidentale. Marine Life 15 (1-2): 63-66.

Lipej L., Mavrič B., Dulčić J. 2014. First record of Chrysiptera cyanea (Quoy and Gaimard, 1825) (Perciformes: Pomacentridae) in the Mediterranean Sea. Journal of Applied Ichthyology 30 (5): 1053-1055.
DOI: $10.1111 /$ jai.12472

Maceda-Veiga A., Escribano-Alacid J., de Sostoa A., García-Berthou E. 2013. The aquarium trade as a potential source of fish introductions in southwestern Europe. Biological Invasions 15 (12): 2707-2716.

DOI: $10.1007 / \mathrm{s} 10530-013-0485-0$

Monteiro-Neto C., Cunha F.E.D.A., Nottingham M.C., Araújo M.E., Rosa I.L., Barros G.M.L. 2003. Analysis of the marine ornamental fish trade at Ceará State, northeast Brazil. Biodiversity and Conservation 12 (6): 1287-1295.

DOI: $10.1023 / \mathrm{A}: 1023096023733$

Morrisey D., Inglis G., Neil K., Bradley A., Fitridge I. 2011. Characterization of the marine aquarium trade and management of associated marine pests in Australia, a country with stringent import biosecurity regulation. Environmental Conservation 38 (1): 89-100. DOI: $10.1017 /$ S0376892911000014

Mouneimné N. 1979. Poissons nouveaux pour les cotes libanaises. Cybium 6: 105-110.

Padilla D.K., Williams S.L. 2004. Beyond ballast water: Aquarium and ornamental trades as sources of invasive species in aquatic ecosystems. Frontiers in Ecology and the Environment 2 (3): 131-138.

DOI: 10.1890/1540-9295(2004)002[0131:BBWAAO]2.0.CO;2

Papavlasopoulou I., Vardakas L., Perdikaris C., Kommatas D., Paschos I. 2014. Ornamental fish in pet stores in Greece: A threat to biodiversity? Mediterranean Marine Science 15 (1): 126-134. DOI: $10.12681 / \mathrm{mms} .484$

Rhyne A.L., Tlusty M.F., Schofield P.J., Kaufman L., Morris J.A.jr., Bruckner A.W. 2012. Revealing the appetite of the marine aquarium fish trade: The volume and biodiversity of fish imported into the United States. PLoS ONE 7 (5): e35808.

DOI: 10.1371 /journal.pone.0035808

Rothman S.B., Goren M. 2015. First record of the Red Sea shrimp-goby Cryptocentrus caeruleopunctatus in the Mediterranean Sea. Marine Biodiversity Records 8: e157.

DOI: $10.1017 / \mathrm{S} 1755267215001323$

Salameh P., Sonin O., Edelist D. Golani D. 2012. The first substantiated record of the yellowbar angelfish, Pomacanthus maculosus (Actinopterygii: Perciformes: Pomacanthidae) in the Mediterranean. Acta Ichthyologica et Piscatoria 42 (1): 73-74. DOI: $10.3750 / A I P 2011.42 .1 .10$

Santini F., Sorenson L., Alfaro M.E. 2013. A new phylogeny of tetraodontiform fishes (Tetraodontiformes, Acanthomorpha) based on 22 loci. Molecular Phylogenetics and Evolution 69 (1): 177-187. DOI: 10.1016/j.ympev.2013.05.014

Tsadok R., Shemesh E., Popovich Y., Sabag Y., Golani D., Tchernov D. 2015. New record and occurrence of the Red Sea bannerfish, Heniochus intermedius (Actinopterygii: Perciformes: Chaetodontidae), in the Mediterranean. Acta Ichthyologica et Piscatoria. 45 (3): 331-333.

DOI: $10.3750 / A I P 2015.45 .3 .14$ 
Vacchi M., Psomadakis P.N., Repetto N., Würtz M. 2010. First record of the dog snapper Lutjanus jocu in the Mediterranean Sea. Journal of Fish Biology 76 (3): 723-728.

DOI: $10.1111 / \mathrm{j} .1095-8649.2009 .02505 . \mathrm{x}$

Vella A., Agius Darmanin S., Vella N. 2015a. Morphological and genetic barcoding study confirming the first Stegastes variabilis (Castelnau, 1855) report in the Mediterranean Sea. Mediterranean Marine Science 16 (3): 609-612.

DOI: $10.12681 / \mathrm{mms} .1391$

Vella A., Vella N., Agius Darmanin S. 2015b. First record of Lutjanus fulviflamma (Osteichthyes: Lutjanidae) in the Mediterranean Sea. Journal of the Black Sea/ Mediterranean Environment 21 (3): 307-315.

Vella A., Vella N., Agius Darmanin S. 2016. The first record of the African sergeant, Abudefduf hoefleri (Perciformes: Pomacentridae), in the Mediterranean Sea. Marine Biodiversity Records 9: 15.

DOI: $10.1186 / \mathrm{s} 41200-016-0008-7$

Weigle S.M., Smith L.D., Carlton J.T. Pederson J. 2005. Assessing the risk of introducing exotic species via the live marine species trade. Conservation Biology 19 (1): 213-223.

DOI: $10.1111 / \mathrm{j} .1523-1739.2005 .00412 . x$
Weitzmann B., Mercader L., Azzurro E. 2015. First sighting of Zebrasoma flavescens (Teleostei: Acanthuridae) and Balistoides conspicillum (Teleostei: Balistidae) in the Mediterranean Sea: Two likely aquarium releases. Mediterranean Marine Science 16 (1): $147-150$.

DOI: $10.12681 / \mathrm{mms} .963$

WoRMS Editorial Board 2016. World Register of Marine Species. Available from http://www.marinespecies.org at VLIZ. Accessed 2016-01-05.

Zammit E., Schembri P.J. 2011. An overlooked and unexpected introduction? Occurrence of the spotted scat Scatophagus argus (Linnaeus, 1766) (Osteichthyes: Scatophagidae) in the Maltese Islands. Aquatic Invasions 6 (Suppl. 1): S79-S83.

DOI: 10.3391/ai.2011.6.S1.018

Zenetos A., Gofas S., Morri C., Rosso A., Violanti D., García Raso J.E., Çinar M.E., Almogi-Labin A., Ates A.S., Azzurro E., Ballesteros E., Bianchi C.N., Bilecenoglu M., Gambi M.C., Giangrande A., Gravili C., Hyams-Kaphzan O., Karachle V., Katsanevakis S., Lipej L., Mastrototaro F., Mineur F., PancucciPapadopoulou M.A., Ramos Esplá A., Salas C., San Martín G., Sfriso A., Streftaris N., Verlaque M. 2012. Alien species in the Mediterranean Sea by 2012. A contribution to the application of European Union's Marine Strategy Framework Directive (MSFD). Part 2. Introduction trends and pathways. Mediterranean Marine Science 13 (2): 328-352.

DOI: $10.12681 / \mathrm{mms} .327$

Received: 5 February 2016

Accepted: 2 September 2016 Published electronically: 30 September 2016 